\title{
PENGARUH KEPEMIMPINAN, MOTIVASI KERJA DAN KOMITMEN ORGANISASI TERHADAP KINERJA PEGAWAI UPTD PASAR WONOKRIYO GOMBONG
}

\author{
Erlagista Eka Saputri ${ }^{1}$; Dani Rizana ${ }^{2}$ \\ STIE Putra Bangsa Jl. Ronggowarsito No. 18 Pejagoan, Kebumen \\ Email: erlagistaeka58@gmail.com ${ }^{1}$, danirizana@gmail.com ${ }^{2}$
}

\begin{abstract}
The purpose of this quantitative descriptive explanatory survey study was to find out the influence of leadership, work motivation, and organizational commitment to the performance of employees UPTD Pasar Wonokriyo Gombong. The problem in this research was the decreasing performance of employee UPTD caused by leadership, work motivation, and organizational commitment. The number of samples taken was 34 employe with saturated sample method or using the entire population. Data collection using a Likert-scale closed questionnaire. Data analysis used quantitative analysis and the method was validity and reliability test, classical assumption test, multiple linear regression analysis and t test, $F$ test and coefficient of determination test (Adjusted $R$ Square). The result of this research shows that leadership, work motivation, and organizational commitment give positive and significant influence to performance either partially or simultaneously. $R^{2}$ value obtained 0.395 which means leadership, work motivation, and organizational commitment give the effect of 39,5\% on performance and the remaining 60,5\% caused by other factors.
\end{abstract}

Keywords: Leadership, Work Motivation, Organizational Commitment, Performance

\section{PENDAHULUAN}

Masalah sumber daya manusia masih menjadi sorotan dan tumpuhan bagi organisasi untuk tetap bertahan di era globalisasi. Dalam era globalisasi saat ini, suatu organisasi atau lembaga institusi dituntut untuk mengadakan penyesuaianpenyesuaian dalam semua segi yang ada pada organisasi tersebut. Menurut Robbins dan Jugde (2007) (dalam Burhanudin, 2015) organisasi adalah suatu unit sosial yang terdiri dari dua orang atau lebih, dikoordinasi secara sadar, dan berfungsi dalam suatu dasar yang relatif terusmenerus untuk mencapai tujuan. Tujuan organisasi tidak mungkin terwujud tanpa peran pegawai meskipun alat-alat yang

Vol. 11, No. 1, Januari 2020, Halaman 85-104 dimiliki organisasi begitu canggih. Keberhasilan organisasi tidak hanya tergantung pada teknologi organisasi melainkan juga tergantung pada aspek sumber daya manusia yang dimiliki organisasi sehingga organisasi membutuhkan sumber daya manusia yang potensial, baik pemimpin maupun pegawai yang dapat memberikan kontribusi dengan baik dan melaksanakan tugas secara optimal.

Sudarmanto (2009), untuk mengetahui sejauh mana peran dan kontribusi sumber daya manusia dalam mencapai keberhasilan organisasi, tentu diperlukan pengukuran atau penilaian kinerja. Menurut Mondy dan Noe (2005), 
penilaian kinerja adalah tinjauan formal dan evaluasi kinerja individu atau tugas tim. Menurut Dessler (2016: 330), penilaian kerja adalah mengevaluasi kinerja organisasi dimana sekarang atau dimasa lalu secara relatif terhadap standar kinerjanya. Pengukuran atau penilaian kinerja dituangkan dalam bentuk SKP (Sasaran Kerja Pegawai). SKP (Sasaran Kerja Pegawai) merupakan tolak ukur kinerja setiap pegawai selama kurun waktu satu tahun.

Kinerja adalah hasil kerja secara kualitas yang dicapai oleh seorang pegawai dalam melaksanakan tugas sesuai dengan tanggung jawab yang diberikan kepadanya (Mangkunegara, 2011). Kinerja adalah hasil kerja yang dapat dicapai oleh seseorang atau sekelompok orang dalam suatu organisasi (Moeheriono, 2010). Kinerja pada dasarnya mencangkup sikap mental dan perilaku yang selalu mempunyai pandangan bahwa pekerjaan yang dilaksanakan saat ini harus lebih berkualitas daripada pelaksaan pekerjaan masa lalu, untuk saat yang akan datang lebih berkualitas daripada saat ini. Secara teori terdapat faktor-faktor yang berhubungan dengan kinerja pegawai. Faktor-faktor tersebut bisa saja bersumber dari organisasi, dari pegawai itu sendiri maupun dari faktor luar pegawai dan organisasi.

UPTD pasar Wonokriyo Gombong merupakan salah satu UPTD dibawah naungan Dinas Perindustrian dan Perdagangan Kabupaten Kebumen yang bertugas di bidang pendapatan retribusi. Melihat dari permasalahan kinerja pegawai UPTD pasar Wonokriyo Gombong menunjukkan kinerja kurang optimal. Hal

Vol. 11, No. 1, Januari 2020, Halaman 85-104 tersebut dapat tergambarkan pada tindakan, yaitu nilai hasil kerja pegawai yang menurun.

Berikut data nilai capaian SKP (sasaran kerja pegawai) di UPTD pasar Wonokriyo Gombong dinyatakan dengan grafik dan angka:

Grafik I-1
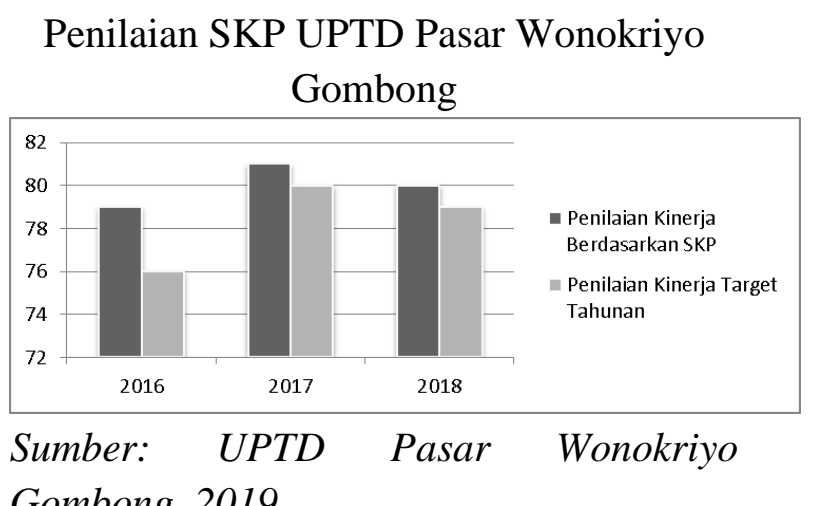

Gombong, 2019

Dari data diatas dapat dilihat bahwa penilaian kinerja berdasarkan hasil SKP (sasaran kerja pegawai) UPTD pasar Wonokriyo Gombong pada tahun 2016 diperoleh nilai sebesar 79 dan untuk nilai SKP (sasaran kerja pegawai) target tahunan sebesar 76. Penilaian kinerja SKP (sasaran kerja pegawai) tahun 2017 sebesar 81 sementara penilaian target tahunan sebesar 80. Dapat dikatakan penilaian kinerjanya mengalami kenaikan dari tahun 2016-2017. Pada tahun 2018 penilaian SKP (sasaran kerja pegawai) mengalami penurunan 80 dan penilaian target tahunan sebesar 79. Hal ini disebabkan target tahunan mengalami penurunan karena pegawai belum melaksankan sesuai dengan tugas pokoknya. Target tahunan merupakan hasil dari pendapatan retribusi. Selain SKP penilaian kinerja pegawai juga dilihat dari 
diadakannya evaluasi rutin setiap bulan, tujuannya untuk meningkatkan kinerja pegawai dari waktu kewaktu. Permasalahan mengenai kinerja merupakan permasalahan yang selalu dihadapi oleh pihak organisasi, karena itu pihak organisasi perlu mengetahui faktor-faktor yang mempengaruhi kinerja pegawai.

Peranan atasan atau sering disebut pimpinan sangatlah besar bagi keberhasilan organisasi dalam mencapai tujuan. Pemimpin adalah seseorang yang mempergunakan wewenang kepemimpinannya untuk mengarahkan serta bertanggung jawab atas pekerjaan pegawai tersebut dalam mencapai tujuan Hasibuan (2016: 13). Dalam kenyataanya tidak semua pimpinan berperilaku baik dan mampu mengarahkan kinerja pegawainya, banyak dijumpai pimpinan dalam kepemimpinannya bersikap egois, tidak mau bersikap koperatif, tidak mau berkorban dan tidak mau memberikan dorongan untuk member semangat kerja kepada pegawai. Kepemimpinan yang efektif dan kurang memperhatikan pegawainya, biasanya menyebabkan perasaan tidak senang terhadap atasan yang diwujudkan dalam bentuk sikap bermalasmalasan dalam bekerja dan kurang bersemangat dalam menanggapi setiap tugas yang diberikan oleh pimpinan.

Hasil penelitian Wishbay dan Fitri (2014) menunjukkan terdapat pengaruh kepemimpinan terhadap kinerja pegawai. Permasalahan yang ada pada UPTD pasar Wonokriyo Gombong yaitu yang pertama dari faktor pemimpin yang tidak bisa mengarahkan bawahan dengan baik dan tidak tegas dalam mengambil keputusan

Vol. 11, No. 1, Januari 2020, Halaman 85-104 atau tindakan sehingga bawahan merasa tidak nyaman dalam bekerja yang mengakibatkan kinerja pegawai menjadi menurun dan tidak maksimal. Sejalan dengan hal tersebut, faktor kepemimpinan dapat menjadi indikator utama ketidakkesusaian kinerja pegawai yang diharapkan, seperti yang telah dijelaskan sebelumnya bahwa kepemimpinan merupakan salah satu alasan yang dapat mengakibatkan kinerja pegawai turun.

Kemampuan pegawai untuk dapat berprestasi disebabkan dengan adanya dorongan atau motivasi. Motivasi kerja merupakan berbagai dorongan yang muncul pada diri organisasi untuk tugas yang menjadi tanggung jawabnya dengan baik guna kemajuan organisasi (Robbins, 2011: 205). Dorongan tersebut mempunyai kekuatan yang besar dalam penentuan sikap pegawai dalam bekerja. Jika pengaruh yang ditimbulkan besar, maka dorongan kerja besar pula. Dalam organisasi motivasi mempunyai peranan penting karena motivasi menyangkut langsung pada unsur manusia dalam organisasi.

Motivasi yang tepat akan mampu memajukan dan mengembangkan organisasi. Kuat lemahnya motivasi kerja menentukan tinggi rendahnya tingkat kinerja pegawai. Artinya semakin tinggi motivasi kerja pegawai, maka akan semakin tinggi pula kinerja pegawai dan sebaliknya, semakin rendah motivasi kerja pegawai maka akan semakin rendah pula kinerja pegawai. Dorongan seseorang untuk bekerja dipengaruhi adanya kebutuhan yang harus dipenuhi dan tingkat kebutuhan yang berbeda pada setiap pegawai, sehingga 
dapat terjadi perbedaan motivasi dalam berprestasi.

Hasil penelitian yang dilakukan oleh Novyanti (2015) membuktikan bahwa motivasi kerja berpengaruh positif terhadap kinerja pegawai. Faktor permasalahan yang ada pada UPTD pasar Wonokriyo Gombong terkait dengan penurunan motivasi kerja pegawai UPTD pasar Wonokriyo Gombong yaitu kurangnya pemberian penghargaan (reward) bagi pegawai yang berprestasi sehingga pegawai kurang termotivasi untuk bekerja. Bagi seorang pemimpin harus memberikan reward kepada pegawainya guna memotivasi sehingga pegawai dapat melaksanakan pekerjaan secara maksimal.

$$
\text { Selain motivasi, untuk }
$$

meningkatkan kinerja pegawai disuatu organisasi pempimpin mampu membuat pegawai memiliki komitmen organisasi yang tinggi. Komitmen merupakan sikap loyalitas pegawai terhadap organisasi dan juga merupakan suatu proses mengekspresikan perhatian dan partisipasinya terhadap organisasi (Sutrisno, 2011: 296). Komitmen terhadap organisasi artinya lebih dari sekedar keanggotaan formal, karena meliputi sikap menyukai organisasi, dan kesediaan untuk mengusahakan tingkat upaya yang tinggi bagi kepentingan organisasi demi tercapainya tujuan organisasi. Berdasarkan uraian tersebut, komitmen organisasi mencakup unsur loyalitas terhadap organisasi, keterlibatan dalam pekerjaan, indentifikasi terhadap nila-nilai dan tujuan organisasi. Pegawai yang mempunyai komitmen organisasi yang tinggi akan cenderung mempunyai kinerja yang baik.

Vol. 11, No. 1, Januari 2020, Halaman 85-104
Hasil penelitian yang dilakukan oleh Suwardi dan Utomo (2011) membuktikan bahwa komitmen organisasi berpengaruh positif terhadap kinerja pegawai. Berdasarkan observasi awal penulis yang dilakukan di UPTD pasar Wonokriyo Gombong yaitu beberapa pegawai tidak mau menerima resiko dari pekerjaanya sehingga tidak terlalu loyal pada pekerjaan tersebut dan rendahnya kontribusi pegawai kepada instansi, dimana saat dilaksanakan rapat tidak semua pegawai yang hadir dan dalam rapat pegawai kurang aktif memberikan aspirasinya.

Berdasarakan uraian diatas, penulis tertarik untuk melakukan penelitian dan pengajian secara lebih mendalam terhadap masalah tersebut dengan judul: "Pengaruh Kepemimpinan, Motivasi Kerja dan Komitmen Organisasi Terhadap Kinerja Pegawai UPTD Pasar Wonokriyo Gombong”.

\section{LANDASAN TEORI}

\section{Kinerja}

Kinerja adalah tentang melakukan pekerjaan dari hasil yang dicapai dari pekerjaan tersebut, ada enam indikator yang dikemukakan oleh Robbins dalam Bahari (2016: 21). Kinerja adalah hasil secara kualitas dan kuantitas yang dicapai oleh seorang pegawai dalam melaksanakan tugasnya sesuai dengan tanggung jawab yang diberikan kepadanya (Mangkunegara, 2009: 13).

\section{Faktor-Faktor Yang Mempengaruhi Kinerja}


Faktor-faktor yang mempengaruhi kinerja karyawan baik hasil maupun perilaku kerja menurut (Kasmir, 2016:189193) yaitu kemampuan dan keahlian, pengetahuan, rancangan kerja, kepribadian, motivasi kerja, kepemimpinan, gaya kepemimpinan, budaya organisasi, kepuasan kerja, lingkungan kerja, komitmen dan disiplin kerja.

\section{Indikator Kinerja}

Terdapat enam indikator yang
dikemukakan oleh Robbins dalam
(Mangkunegara, 2011:75) yaitu:

a. Kualitas dari pekerjaan, yaitu mutu hasil pekerjaan dengan mempertimbangkan keakuratan, keahlian, dan dapat dipercaya.

b. Kuantitas dari pekerjaan, yaitu jumlah dari pekerjaan yang bermanfaat pada periode waktu sejak penilaian terakhir, dibandingkan dengan standar kerja yang telah dibuat.

c. Tanggung jawab pegawai terhadap organisasinya.

d. Kerja sama, yaitu kesadaran akan kewajiban pegawai untuk melaksakan pekerjaan yang diberikan organisasi.

e. Inisiatif, mempunyai kemampuan dalam mengerjakan tugas dan mempunyai inisiatif.

\section{Kepemimpinan}

Kepemimpinan adalah kemampuan untuk mempengaruhi suatu kelompok kearah pencapaian tujuan (Robbins, 2015: 410). Menurut Hersey (2004: 29) kepemimpinan adalah proses untuk mempengaruhi aktivitas individu atau

Vol. 11, No. 1, Januari 2020, Halaman 85-104 kelompok dalam rangka mencapai tujuan yang telah ditetapkan.

\section{Fungsi Kepemimpinan}

Fungsi kepemimpinan berhubungan langsung dengan situasi sosial dalam kehidupan berkelompok atau instansi masing-masing yang mengisyaratkan bahwa setiap pemimpin berada didalam dan bukan diluar situasi tersebut. Secara operasional Veitzhal Rivai (2013: 34), yaitu:
a. Fungsi instruksi
b. Fungsi konsultasi
c. Fungsi partisipatif
d. Fungsi delegasi
e. Fungsi pengendalian

\section{Indikator}

Menururt Sondang (2003: 97) indikator kepemimpinan, sebagai berikut:

a. Iklim saling mempercayai

b. Perhatian pada kenyamanan kerja bagi para bawahan

c. Perhatian pada kesejahteraan bawahan

d. Membuat model pemecahan

e. Pengakuan atas status para bawahan secara tepat dan professional

\section{Motivasi Kerja}

Motivasi Kerja merupakan kekuatan yang mendorong seseorang untuk melakukan suatu tindakan atau pada pada hakekatnya ada secara internal dan eksternal yang dapat positif atau negatif mengarahkannya (Ardana, 2012: 193). 
Menurut Robbins dan Judge (2015: 55) motivasi sebagai bentuk proses mengenai kekuatan arah dan ketekunan seseorang dalam mencapai tujuan yang sudah ditentukan sebelumnya.

\section{Indikator Motivasi Kerja}

Menurut Handoko (2011: 10) indikator motivasi kerja, sebagai berikut:
a. Penghargaan
b. Pekerjaan kreatif dan menantang
c. Kemajuan dan peningkatan
d. Kondisi kerja

\section{Komitmen Organisasi}

Komitmen organisasi adalah sampai tingkat mana seseorang karyawan memihak pada suatu organisasi tertentu dan tujuantujuannya, dan berniat memelihara keanggotaan dalam organisasi itu. Menurut Luthas dalam Hardianti (2014) menyatakan komitmen organisasi merupakan sikap yang mereflesikan loyalitas karyawan pada organisasi dan proses berkelanjutan dimana anggota organisasi mengekspresikan perhatiannya terhadap organisasi dan keberhasilan serta kemajuan yang berkelanjutan.

\section{Indikator Komitmen Organisasi}

Menurut Robbins dan Jugde dalam Zelvia (2015) adalah sebagai berukut:
a. Komitmen afektif (affective commitment)
b. Komitmen bekerlanjutan (continuance commitment)

Vol. 11, No. 1, Januari 2020, Halaman 85-104 c. Komitmen normatif (normative
commitment)

\section{MODEL EMPIRIS}

Gambar 1

Model Empiris

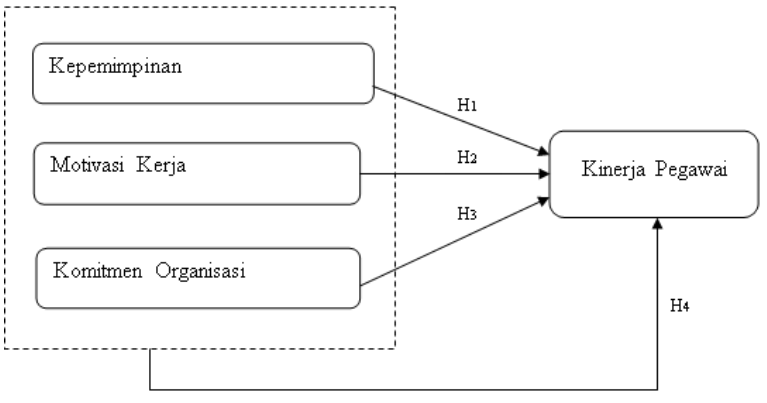

\section{HIPOTESIS PENELITIAN}

$\mathrm{H}_{1} \quad$ Terdapat pengaruh kepemimpinan

: terhadap kinerja pegawai UPTD pasar Wonokriyo Gombong.

$\mathrm{H}_{2} \quad$ Terdapat pengaruh motivasi kerja

: terhadap kinerja pegawai UPTD pasar Wonokriyo Gombong.

$\mathrm{H}_{3}$ Terdapat pengaruh komitmen

: $\quad$ organisasi terhadap kinerja pegawai UPTD pasar Wonokriyo Gombong.

$\mathrm{H}_{4} \quad$ Terdapat pengaruh secara simultan : kepemimpinan, motivasi kerja dan komitmen organisasi terhadap kinerja pegawai UPTD pasar Wonokriyo Gombong.

\section{METODE}

Pendekatan kuantitatif merupakan pendekan yang dipilih oleh peneliti pada penelitian kali ini. Menurut Sugiyono 
(2008:13) metode pendekatan kuantitatif ini digunakan Peneliti untuk meneliti populasi atau sampel penelitian secara acak dimana pengumpulan data menggunakan instrument penelitian dan menggunakan analisis statistik.

\section{Populasi dan Sampel}

Populasi dalam penelitian ini adalah semua pegawai pada kantor UPTD pasar Wonokriyo Gombong yang berjumlah 34 orang.. Dalam penelitian ini teknik pengambilan sampel dilakukan dengan teknik sampel jenuh yaitu sebanyak 34 orang pegawai.

\section{Teknik Pengumpulan Data}

Pengumpulan data yang dimaksud untuk memperoleh bahan-bahan yang relevan dan akurat melalui wawancara, studi pustaka dan angket/kuesioner Seluruh variabel akan diukur menggunakan skala Likert.

\section{Teknik Analisis}

Teknik analisis data merangkum sejumlah data besar yang dapat memberikan informasi tentang pengalaman dan pemahaman karakteristik responden atau sifat-sifat data tersebut dapat menjawab permasalahan dalam kegiatan penelitian. Teknik analisis data dapat dibedakan menjadi Analisis Deskriptif dan Analisis Statistik dengan menggunakan bantuan program SPSS 23 for windows (Statistical Product and Services Solution).
Analisis Statistik di penelitian ini memuat Uji validitas, uji reliabilitas, uji asumsi klasik yang berupa multikolinieritas, heteroskedastisitas dan normalitas, lalu analisis regresi linier berganda, uji parsial (uji t), uji simultan (uji F) dan koefisien determinasi.

\section{HASIL DAN PEMBAHASAN}

\section{Analisis Deskriptif}

Klasifikasi responden berdasarkan umur dapat dilihat pada tabel berikut:

Tabel 1

Karakteristik Responden Berdasarkan Umur

\begin{tabular}{llll}
\hline No & $\begin{array}{l}\text { Umur } \\
\text { (Tahun) }\end{array}$ & $\begin{array}{l}\text { Jumlah } \\
(\text { Orang) }\end{array}$ & $\begin{array}{l}\text { Prosentase } \\
(\boldsymbol{\%})\end{array}$ \\
\hline 1. & $20-30$ & 9 & $26,5 \%$ \\
2. & $31-40$ & 12 & $35,3 \%$ \\
3. & $41-50$ & 9 & $26,5 \%$ \\
4. & $>50$ & 4 & $11,7 \%$ \\
\hline & Jumlah & 34 & 100 \\
\hline
\end{tabular}

Sumber: Data Primer Diolah, 2020

Karakteristik responden berdasarkan umur dari 34 responden terdapat 9 orang responden atau $26,5 \%$ mempunyai umur antara 20-30 tahun, 12 orang responden atau $35,3 \%$ mempunyai umur antara $31-40$ tahun, 9 orang responden atau $26,5 \%$ mempunyai umur antara 41-50 tahun, dan 4 orang responden atau $11,7 \%$ mempunyai umur lebih dari 50 tahun.

Klasifikasi responden berdasarkan pendidikan dapat dilihat pada tabel berikut: 
Tabel 2

Karakteristik Responden Berdasarkan Pendidikan

\begin{tabular}{|c|c|c|c|}
\hline No & Pendidikan & $\begin{array}{l}\text { Jumlah } \\
\text { (Orang) }\end{array}$ & $\begin{array}{l}\text { Prosentase } \\
(\%)\end{array}$ \\
\hline 1. & SD & 1 & $2,9 \%$ \\
\hline 2. & SMP & 3 & $8,8 \%$ \\
\hline 3. & SMA & 29 & $85,4 \%$ \\
\hline 4. & D3 & 0 & $0 \%$ \\
\hline \multirow[t]{2}{*}{5.} & $\mathrm{~S} 1$ & 1 & $2,9 \%$ \\
\hline & Jumlah & 34 & 100 \\
\hline
\end{tabular}

Karakteristik responden berdasarkan pendidikan dari 34 responden terdapat 1 orang responden atau 2,9\% mempunyai pendidikan SD, 3 orang responden atau $8,8 \%$ mempunyai pendidikan SMP, 29 orang responden atau $85,4 \%$ mempunyai pendidikan SMA, 1 orang responden atau 2,9\% mempunyai pendidikan S1 dan tidak ada responden yang mempunyai pendidikan D3.

Klasifikasi responden berdasarkan lama kerja dapat dilihat pada tabel berikut:

Tabel 3

Karakteristik Responden Berdasarkan Lama Kerja

\begin{tabular}{llll}
\hline No & $\begin{array}{l}\text { Lama } \\
\text { Kerja } \\
\text { (Tahun) }\end{array}$ & $\begin{array}{l}\text { Jumlah } \\
\text { (Orang) }\end{array}$ & $\begin{array}{l}\text { Prosentase } \\
(\%)\end{array}$ \\
\hline 1. & $1-5$ & 3 & $8,8 \%$ \\
2. & $6-10$ & 18 & $53 \%$ \\
3. & $>10$ & 13 & $38.2 \%$ \\
\hline & Jumlah & $\mathbf{3 4}$ & $\mathbf{1 0 0}$ \\
\hline
\end{tabular}

Sumber: Data Primer Diolah, 2020 


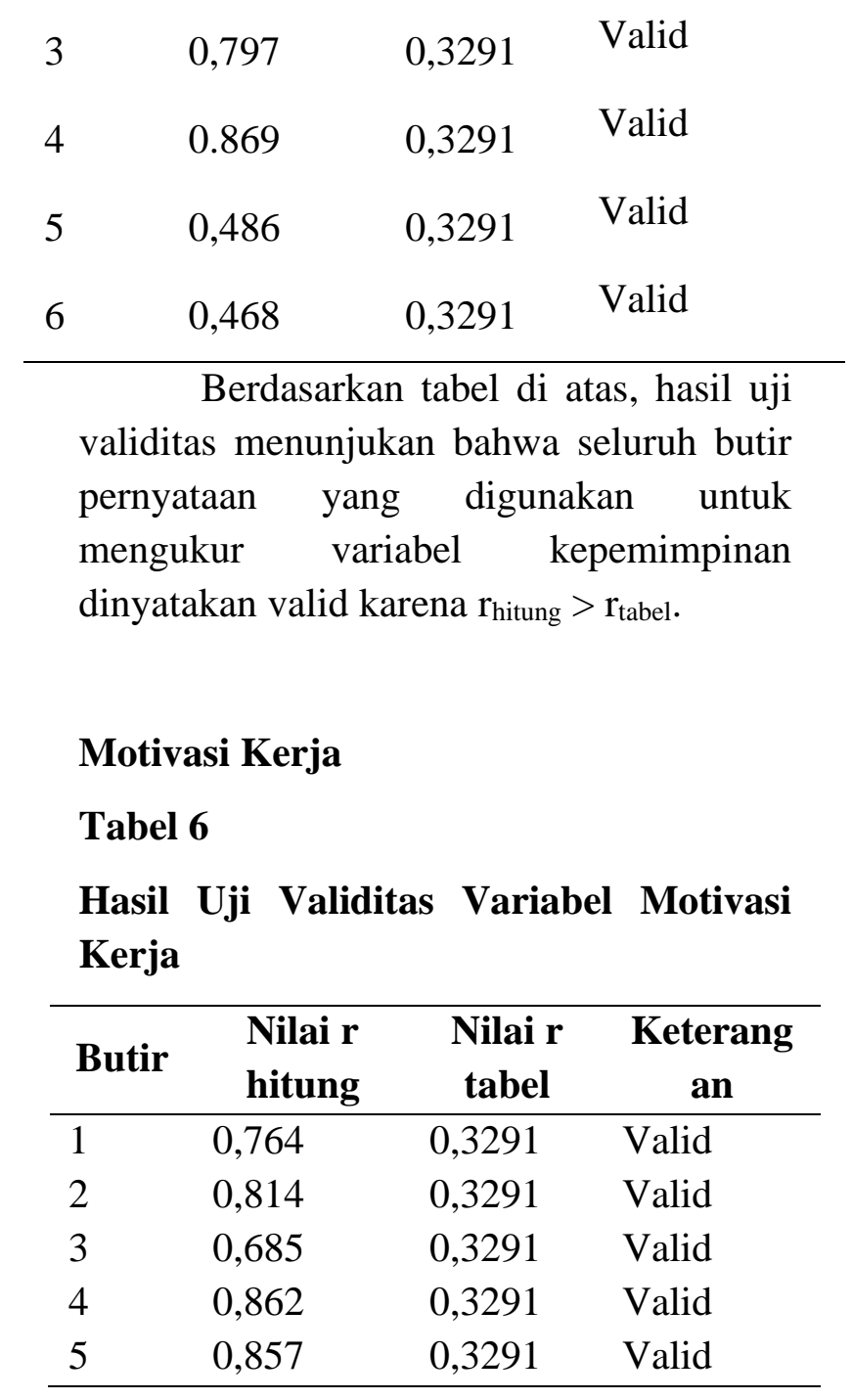

Berdasarkan tabel diatas, hasil uji validitas menunjukan bahwa semua seluruh butir pernyataan yang digunakan untuk mengukur variabel motivasi kerja dinyatakan dinyatakan valid karena $\boldsymbol{r}_{\text {hitung }}>$ $r_{\text {tabel. }}$.

\section{Komitmen Organisasi}

Tabel 7

\section{Hasil Uji Validitas Variabel Komitmen Organisasi}

Vol. 11, No. 1, Januari 2020, Halaman 85-104

\begin{tabular}{llcl}
\hline Butir & $\begin{array}{c}\text { Nilai } \mathbf{r} \\
\text { hitung }\end{array}$ & $\begin{array}{c}\text { Nilai } \mathbf{r} \\
\text { tabel }\end{array}$ & Keterangan \\
\hline 1 & 0,857 & 0,3291 & Valid \\
2 & 0,644 & 0,3291 & Valid \\
3 & 0,840 & 0,3291 & Valid \\
4 & 0,698 & 0,3291 & Valid \\
5 & 0,487 & 0,3291 & Valid \\
\hline
\end{tabular}

Berdasarkan tabel diatas, hasil uji validitas menunjukan bahwa seluruh butir pernyataan yang digunakan untuk mengukur variabel komitmen organisasi dinyatakan valid karena $r_{\text {hitung }}>r_{\text {tabel}}$.

\section{Kinerja}

\section{Tabel 8}

\section{Hasil Uji Validitas Variabel Kinerja}

\begin{tabular}{llcl}
\hline Butir & $\begin{array}{c}\text { Nilai } \mathbf{r} \\
\text { hitung }\end{array}$ & $\begin{array}{c}\text { Nilai } \mathbf{r} \\
\text { tabel }\end{array}$ & Keterangan \\
\hline 1 & 0,756 & 0,3291 & Valid \\
2 & 0,800 & 0,3291 & Valid \\
3 & 0,550 & 0,3291 & Valid \\
4 & 0,668 & 0,3291 & Valid \\
5 & 0,747 & 0,3291 & Valid \\
\hline
\end{tabular}

Berdasarkan tabel diatas, hasil uji validitas menunjukan bahwa seluruh butir pernyataan yang digunakan untuk mengukur variabel kinerja dinyatakan valid karena $r_{\text {hitung }}>r_{\text {tabel. }}$.

\section{Uji Reliabilitas}

Suatu instrumen dikatakan reliabel apabila memiliki nilai Cronbach Alpha > 0,60 (Ghozali, 2005:129). Uji reliabilitas dilakukan dengan menggunakan rumus Alpha Cronbach dengan bantuan program 
SPSS Statistic 23.0 for Windows. Berikut adalah hasil dari uji reliabilitas:

Tabel 9

\section{Hasil Uji Reliabilitas}

\begin{tabular}{lll}
\hline \multicolumn{1}{c}{ Variabel } & $\begin{array}{c}\text { Cronbach } \\
\text { Alpha }\end{array}$ & Keterangan \\
\hline Kepemimpinan & 0,808 & Reliabel \\
Motivasi Kerja & 0,857 & Reliabel \\
Komitmen & 0,764 & Reliabel \\
Organisasi & & \\
Kinerja & 0,738 & Reliabel \\
\hline
\end{tabular}

Berdasarkan tabel di atas dapat dilihat bahwa nilai Alpha Cronbach semua variabel menunjukan lebih dari 0,60. Sehingga, dapat dinyatakan bahwa jawaban-jawaban responden dari variabelvariabel tersebut reliabel, sehingga kuesioner dari variabel-variabel tersebut dapat digunakan untuk penelitian selanjutnya.

\section{UJI ASUMSI KLASIK}

Uji Multikolinieritas

Deteksi ada tidaknya multikolinieritas yaitu dengan melihat besarnya nilai $\mathrm{VIF} \leq 10$ dan nilai tolerance $\geq 0,10$ (10\%). Hasil uji multikolinieritas dapat dilihat pada tabel berikut:

\section{Tabel 10}

\section{Hasil Uji Multikolinearitas}

\begin{tabular}{lcll}
\hline No & Variabel & Tolerance & VIF \\
\hline 1 & Kepemimpinan & 0,997 & 1,003
\end{tabular}

\begin{tabular}{llll}
2 & Motivasi Kerja & 0,971 & 1,030 \\
3 & Komitmen & 0,968 & 1,033 \\
& Organisasi & & \\
\hline
\end{tabular}

Berdasarkan tabel diatas, dapat diketahui bahwa semua variabel memiliki nilai VIF < 10 dan nilai tolerance $>0,10$. Jadi dapat disimpulkan bahwa tidak terjadi multikolinearitas antar variabel independen dalam regresi ini.

\section{Uji Heteroskedastisitas}

\section{Gambar 2}

\section{Hasil Uji Heteroskedastisitas}

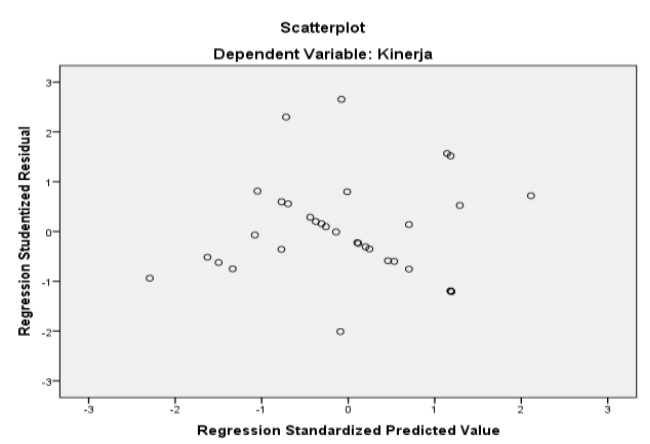

Berdasarkan gambar diatas, menunjukkan bahwa grafik plot tidak membentuk pola yang jelas, maka tidak terjadi heteroskedastisitas atau dapat dikatakan bahwa data homokesdastisitas sehingga asumsi tidak terjadi heteroskedastisitas terpenuhi.

\section{Uji Normalitas}

\section{Gambar 3}

Grafik Uji Normalitas 


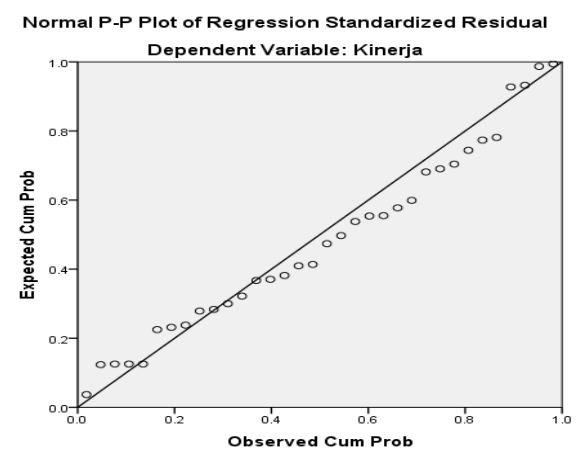

Berdasarkan gambar diatas, menunjukkan bahwa distribusi data residual normal dan garis yang menggambarkan data sesungguhnya mengikuti garis diagonalnya, sehingga dapat disimpulkan bahwa data normal.

\section{ANALISIS REGRESI BERGANDA}

\section{Tabel 11}

Hasil Uji Regresi Linier Berganda

\begin{tabular}{lccc}
\hline & $\begin{array}{c}\text { Unstandarized } \\
\text { B }\end{array}$ & T & Sig \\
\hline (Constant) & 5,551 & 2,3 & 0,028 \\
Kepemimpi & & 15 & \\
nan & 0,297 & 3,2 & 0,003 \\
Motivasi & & 87 & \\
Kerja & 0,159 & 2,5 & 0,018 \\
Komitmen & 0,169 & 04 & \\
Organisasi & & 2,0 & 0,046 \\
\hline
\end{tabular}

Berdasarkan tabel IV-15 diatas dapat dilihat persamaan regresinya sebagai berikut:

$\mathrm{Y}=\mathbf{5 , 5 5 1}+0,297 \mathrm{X} 1+0,159 \mathrm{X} 2+0,169 \mathrm{X3}$

$+\mathbf{e}$

Vol. 11, No. 1, Januari 2020, Halaman 85-104
Berdasarkan persamaan diatas, maka dapat ditentukan sebagai berikut :

1. Konstanta (a) sebesar 5,551 menunujukkan bahwa nilai konstanta atau nilai tetap kinerja yang tidak terpengaruh oleh variabel kepemimpinan, motivasi kerja, dan komitmen organisasi maka nilai kinerja sebesar 5,551 poin.

2. Variabel Independen

a. $\mathrm{b} 1=0,297$

Koefisien regresi untuk X1 sebesar 0,297 artinya kepemimpinan (X1) memiliki pengaruh yang positif terhadap kinerja. Jika variabel kepemimpinan (X1) dinaikan satu poin sementara variabel lain (motivasi kerja dan komitmen organisasi) tetap maka nilai kinerja akan naik sebesar 0,297 poin.

b. $\mathrm{b} 2=0,159$

Koefisien regresi untuk X2 sebesar 0,159 artinya motivasi kerja (X2) memiliki pengaruh yang positif terhadap kinerja. Jika variabel motivasi kerja (X2) dinaikan satu poin sementara variabel lain (kepemimpinan dan komitmen organisasi) tetap maka nilai kinerja akan naik sebesar 0,159 poin.

c. $\mathrm{b} 3=0,169$

Koefisien regresi untuk X3 sebesar 0,169 artinya komitmen organisasi (X3) memiliki pengaruh yang positif terhadap kinerja. Jika variabel komitmen organisasi (X3) dinaikan satu poin sementara variabel lain (kepemimpinan dan motivasi kerja) 
tetap maka nilai kinerja akan naik sebesar 0,169 poin.

\section{UJI HIPOTESIS}

\section{Uji Parsial (Uji t)}

Pengujian ini dilakukan untuk mengetahui pengaruh secara parsial antar variabel bebas (kepemimpinan, motivasi kerja dan komitmen organisasi) terhadap variabel terikat (kinerja)

Tabel 12

Hasil Uji Regresi Linier Berganda

\begin{tabular}{llll}
\hline & $\begin{array}{c}\text { Unstandariz } \\
\text { ed B }\end{array}$ & T & Sig \\
\hline (Constant) & 5,551 & $\begin{array}{l}2,31 \\
5\end{array}$ & 0,028 \\
Kepemimpin & 0,297 & 3,28 & 0,003 \\
an & & 7 & \\
Motivasi & 0,159 & 2,50 & 0,018 \\
Kerja & & 4 & \\
Komitmen & 0,169 & 2,08 & 0,046 \\
Organisasi & & 1 & \\
\hline
\end{tabular}

Berdasarkan tabel diatas dapat diketahui bahwa:

a. Variabel kepemimpinan mempunyai nilai thitung sebesar 3,287 lebih besar dari ttabel 2,032 dengan tingkat signifikan 0,003 lebih kecil dari 0,05. Hasil ini menyatakan bahwa kepemimpinan mempunyai pengaruh yang signifikan terhadap tingkat kinerja pegawai UPTD pasar Wonokriyo Gombong.

b. Variabel motivasi kerja mempunyai nilai thitung sebesar 2,504 lebih besar dari ttabel 2,032 dengan tingkat signifikan 0,046 lebih kecil dari 0,05. Hasil ini menyatakan bahwa motivasi kerja mempunyai pengaruh yang signifikan terhadap tingkat kinerja pegawai UPTD pasar Wonokriyo Gombong.

c. Variabel komitmen organisasi mempunyai nilai thitung sebesar 2,081 lebih besar dari ttabel 2,032 dengan tingkat signifikan 0,003 lebih kecil dari 0,05 . Hasil ini menyatakan bahwa komitmen organisasi mempunyai pengaruh yang signifikan terhadap tingkat kinerja pegawai UPTD pasar Wonokriyo Gombong.

\section{Uji Simultan (Uji F)}

Analisis ini digunakan untuk mengetahui secara bersama-sama pengaruh antara variabel bebas terhadap variabel terikat. Hasil uji $\mathrm{F}$ dalam penelitian ini adalah sebagai berikut:

Tabel 13

Hasil Uji Simultan (Uji F)

\begin{tabular}{lcc}
\hline Jumlah Variabel & F & Nilai sig. \\
\hline 4 & 8,180 & 0,000 \\
\hline
\end{tabular}

Berdasarkan tabel diatas diperoleh nilai $F$ sebesar 8,180 dengan tingkat signifikan 0,000 . Dengan rendahnya tingkat probabilitas 0,000 yaitu lebih kecil dari 0,05 maka dapat disimpulkan bahwa secara simultan kepemimpinan, motivasi kerja, dan komitmen organisasi berpengaruh signifikan terhadap kinerja pegawai UPTD pasar Wonokriyo Gombong. 


\section{Koefisien Determinasi}

Koefisien determinasi

$\left(\mathrm{R}^{2}\right)$

menunjukan berapa besar presentase variasi dalam variabel dependen yang dapat dijelaskan oleh variabel independen (Ghozali, 2005: 87).

\section{Tabel 14}

Hasil Uji Koefisien Determinasi

\begin{tabular}{ccc}
\hline R & R Square & $\begin{array}{c}\text { Adjusted R } \\
\text { Square }\end{array}$ \\
\hline 0,671 & 0,450 & 0,395 \\
\hline
\end{tabular}

Berdasarkan tabel diatas hasil
analisis diperoleh nilai koefisien
determinasi sebesar 0,395 atau 39,5\%
menandakan bahwa kepemimpinan (X1),
motivasi kerja (X2), dan komitmen
organisasi (X3) mempunyai sumbangan
pengaruh terhadap kinerja (Y) sebesar
$39,5 \%$ sedangkan sisanya 60,5\%
dipengaruhi oleh variabel lain di luar
variabel yang diteliti dalam penelitian ini.

\section{PEMBAHASAN}

Kepemimpinan berpengaruh terhadap kinerja pegawai UPTD pasar Wonokriyo Gombong

Hasil penelitian ini membuktikan bahwa kepemimpinan berpengaruh signifikan terhadap kinerja pegawai UPTD pasar Wonokriyo Gombong. Hal in dibuktikan dari hasil uji $\mathrm{t}$ kepemimpinan terhadap kinerja didapatkan nilai yang menunjukan bahwa hasil thitung sebesar 3,287 lebih besar dari ttabel 2,032 dengan tingkat signifikan 0,003 lebih kecil dari 0,05

Vol. 11, No. 1, Januari 2020, Halaman 85-104 yang berarti bahwa variabel kepemimpinan mempunyai pengaruh yang signifikan dan bernilai positif terhadap kinerja pegawai UPTD pasar Wonokriyo Gombong.

Berdasarkan hasil uji diatas, menunjukkan bahwa apabila kepemimpinannya tinggi maka kinerja pegawai juga akan meningkat, sedangkan apabila kepemimpinannya rendah maka kinerja pegawainya akan menurun. Hal ini dapat dilihat dari hasil analisis deskriptif variabel kepemimpinan bahwa 25 atau $73,5 \%$ responden menyatakan kepemimpinan di UPTD pasar Wonokriyo Gombong sangat baik, hasil penelitian ini sesuai dengan penelitian yang dilakukan oleh Wishbay dan Fitri (2014) yang menunjukkan bahwa adanya pengaruh kepemimpinan terhadap kinerja pegawai.

\section{Motivasi kerja berpengaruh terhadap kinerja pegawai UPTD pasar Wonokriyo Gombong}

Hasil penelitian ini membuktikan bahwa motivasi kerja berpengaruh signifikan terhadap kinerja pegawai UPTD pasar Wonokriyo Gombong. Hal ini dibuktikan dari hasil uji t motivasi kerja terhadap kinerja didapatkan nilai yang menunjukan bahwa hasil thitung sebesar 2,504 lebih besar dari ttabel 2,032 dengan tingkat signifikan 0,046 lebih kecil dari 0,05 yang berarti bahwa variabel motivasi kerja mempunyai pengaruh yang signifikan dan bernilai positif terhadap kinerja pegawai UPTD pasar Wonokriyo Gombong.

Berdasarkan hasil uji diatas, menunjukkan bahwa bila motivasi kerja 
tinggi maka kinerja pegawai juga akan meningkat, sedangkan apabila motivasi kerjanya rendah maka kinerja pegawainya akan menurun. Hal ini dapat dilihat dari hasil analisis deskriptif variabel motivasi kerja bahwa 11 atau $32,2 \%$ responden menyatakan motivasi kerja di UPTD pasar Wonokriyo Gombong sangat baik, hasil penelitian ini sesuai dengan penelitian yang dilakukan oleh Novyanti (2015) yang menunjukkan bahwa adanya pengaruh motivasi kerja terhadap kinerja pegawai.

\section{Komitmen organisasi berpengaruh signifikan terhadap kinerja pegawai UPTD pasar Wonokriyo Gombong.}

Hasil penelitian ini membuktikan bahwa motivasi komitmen organisasi berpengaruh signifikan terhadap kinerja pegawai UPTD pasar Wonokriyo Gombong. Hal ini dibuktikan dari hasil uji t komitmen organisasi terhadap kinerja didapatkan nilai yang menunjukan bahwa hasil thitung sebesar 2,081 lebih besar dari ttabel 2,032 dengan tingkat signifikan 0,003 lebih kecil dari 0,05 yang berarti bahwa variabel komitmen organisasi mempunyai pengaruh yang signifikan dan bernilai positif terhadap kinerja pegawai UPTD pasar Wonokriyo Gombong.

Berdasarkan hasil uji diatas, menunjukkan bahwa bila komitmen organisasi tinggi maka kinerja pegawai juga akan meningkat, sedangkan apabila komitmen organisasi rendah maka kinerja pegawainya akan menurun. Hal ini dapat dilihat dari hasil analisis deskriptif variabel kepemimpinan bahwa 6 atau 17,7\% \%

Vol. 11, No. 1, Januari 2020, Halaman 85-104 responden menyatakan komitmen organisasi di UPTD pasar Wonokriyo Gombong sangat baik, hasil penelitian ini sesuai dengan penelitian yang dilakukan oleh Suwardi dan Utomo (2011) yang menunjukkan bahwa adanya pengaruh komitmen organisasi terhadap kinerja pegawai.

Kepemimpinan, motivasi kerja, dan komitmen organisasi secara bersamasama berpengaruh signifikan terhadap kinerja pegawai UPTD pasar Wonokriyo Gombong.

Hasil uji $F$ diatas nilai Fhitung sebesar 8,180 dengan tingkat signifikan 0,000, maka dapat disimpulkan bahwa secara simultan kepemimpinan, motivasi kerja, dan komitmen organisasi berpengaruh signifikan terhadap kinerja pegawai UPTD pasar Wonokriyo Gombong. Karena signifikansi lebih kecil dari 0,05, sehingga diartikan bahwa diperlukan peningkatan faktor dan indikator yang berkaitan dengan variabel kepemimpinan, motivasi kerja, dan komitmen organisasi agar dapat meningkatkan kinerja pegawai UPTD pasar Wonokriyo Gombong.

Faktor-faktor yang berupa kepemimpinan, motivasi kerja, dan komitmen organisasi secara bersama-sama merupakan faktor yang dibutuhkan oleh organisasi dikarenakan mampu meningkatkan kinerja seperti perhatian terhadap kesejahteraan pegawai, memberikan contoh solusi terhadap setiap permasalahan, pemberian insentif, menjaga 
kondisi lingkungan kerja yang nyaman, tersedianya fasilitas kerja yang memadahi hingga dilakukannya evaluasi kinerja pegawai untuk meningkatkan motivasi dan komitmen pegawai kinerjanya semakin meningkat.

\section{PENUTUP}

\section{Kesimpulan}

Penelitian ini bertujuan untuk menentukan bagaimana pengaruh faktor terkait kepemimpinan, motivasi kerja, dan komitmen organisasi terhadap kinerja pegawai UPTD pasar Wonokriyo Gombong yang menghasilkan kesimpulan sebagai berikut:

a. Kepemimpinan menunjukkan pengaruh positif dan signifikan terhadap kinerja pegawai UPTD pasar Wonokriyo Gombong. Hal ini menunjukkan bahwa apabila kepemimpinan memberikan pengaruh yang tinggi, maka kinerja pegawai akan meningkat, sedangkan bila kepemimpinan memberikan pengaruh yang rendah maka kinerja pegawainya akan menurun.

b. Motivasi kerja menunjukkan pengaruh positif dan signifikan terhadap kinerja pegawai UPTD pasar Wonokriyo Gombong. Hal ini menunjukkan bahwa apabila motivasi kerja memberikan pengaruh yang tinggi, maka kinerja pegawai akan meningkat, sedangkan bila motivasi kerja memberikan pengaruh yang rendah maka kinerja pegawainya akan menurun.

c. Komitmen organisasi berpengaruh positif dan signifikan terhadap kinerja pegawai UPTD pasar Wonokriyo Gombong. Hal ini menunjukkan bahwa apabila komitmen organisasi memberikan pengaruh yang tinggi, maka kinerja pegawai akan meningkat. Apabila komitmen organisasi memberikan pengaruh yang rendah maka kinerja pegawainya akan menurun.

d. Kepemimpinan, motivasi kerja, dan komitmen organisasi secara bersamasama berpengaruh secara signifikan terhadap kinerja pegawai UPTD pasar Wonokriyo Gombong. Namun masih ada variabel lain yang mempengaruhi kinerja dari pegawai UPTD pasar Wonokriyo Gombong seperti disiplin kerja, semangat kerja, kemampuan dan lain sebagainya.

\section{Keterbatasan}

Beberapa keterbatasan dalam penelitian tersebut, antara lain:

a. Faktor-faktor yang mempengaruhi kinerja pegawai UPTD pasar Wonokriyo Gombong dalam penelitian ini hanya terdiri dari tiga variabel, yaitu kepemimpinan, motivasi kerja, dan komitmen organisasi, sedangkan masih banyak faktor lain yang mempengaruhi kinerja pegawai UPTD pasar Wonokriyo Gombong.

b. Dalam proses pengambilan data, jawaban yang diberikan responden melalui kuesioner terkadang tidak menunjukkan pendapat responden yang sebenarnya, hal ini terjadi karena perbedaan pemikiran, anggapan dan 
pemahaman yang berbeda tiap responden.

Implikasi

a. Implikasi Praktis

Hasil penelitian ini diharapkan menjadi pertimbangan bagi UPTD pasar Wonokriyo Gombong untuk lebih memperhatikan mengenai bentuk kepemimpinan yang diterapkan kepala UPTD pasar Wonoriyo Gombong agar pegawai tidak merasa tertekan dalam mengerjakan pekerjaannya. Pemberian motivasi kerja dan mempertahankan komitmen organisasi sangat diperlukan agar dapat meningkatkan kinerja pegawai.

b. Implikasi Teoritis

1) Penelitian ini telah membuktikan bahwa kinerja berhubungan dengan beberapa faktor internal dan eksternal. Peningkatan kinerja pegawai akan sebanding dengan peningkatan faktor-faktor yang berkaitan. Hal ini diperkuat oleh Kasmir (2016: 182), mengatakan bahwa kinerja merupakan hasil kerja dan perilaku kerja yang telah dicapai dalam menyelesaikan tugas-tugas dan tanggung jawab yang diberikan dalam suatu periode tertentu.

2) Penelitian ini telah membutktikan bahwa kepemimpinan memiliki hubungan erat dengan kinerja pegawai. Hal ini sejalan dengan yang dikemukakan oleh Hersey (2004: 29), yang mengatakan bahwa kepemimpinan merupakan proses

Vol. 11, No. 1, Januari 2020, Halaman 85-104 untuk mempengaruhi aktifitas individu atau kelompok dalam rangka mencapai tujuan yang telah ditetapkan.

3) Penelitian ini telah membutktikan bahwa motivasi kerja memiliki hubungan erat dengan kinerja pegawai. Hal ini sejalan dengan yang dikemukakan Wibowo (2010), yang mengatakan bahwa motivasi kerja merupakan dorongan terhadap serangkaian proses perilaku manusia pada pencapaian tujuan.

4) Penelitian ini telah membuktikan bahwa komitmen organisasi memiliki hubungan erat dengan kinerja pegawai. Hal ini sejalan dengan teori Luthas dalam Hardianti (2014), yang menyatakan bahwa komitmen organisasi merupakan sikap yang merefleksikan loyalitas karyawan pada organisasi dan proses berkelanjutan dimana anggota organisasi mengekspresikan perhatiannya terhadap organisasi dan keberhasilan serta kemajuan yang berkelanjutan.

\section{DAFTAR PUSTAKA}

Ardianti, Hesti. 2019. Pengaruh Motivasi, Quality Of Work Life, Dan Kompensasi Terhadap Kedisiplinan Pegawai (Studi Pada Pegawai PNS Dinas Pendidikan Kabupaten Kebumen). Skripsi Sarjana (Tidak dipublikasikan). Kebumen : STIE Putra Bangsa

Barnawi dan Mohammad Arifin. 2012. Instrumen Pembinaan, Peningkatan, \& 
Penilaian Kinerja Guru Profesional. Jogjakarta: Ar-Ruzz Media

Cascio, Wayne F. 2003. Managing Human Resource. Colorado: Mc Graw-Hill.inc

Dita Asriani, et all. 2015. "Pengaruh Reward Terhadap Disiplin Kerja Karyawan PT. Citra Riau Sarana Kabupaten Kuantan Singingi." Jurnal Online Mahasiswa Fakultas Keguruan dan Ilmu Pendidikan, Vol. 2, No. 2. Diambil 31 Oktober 2019 dari database Perpustakaan Universitas Riau

Djamarah, Syaeful Bahri. 2005. Guru dan Anak Didik dalam Interaksi Anak Didik. Jakarta: Rineka Cipta

Djamarah, Syaeful Bahri. 2008. Psikologi Belajar. Jakarta: Rineka Cipta

Flippo, E.B. 2005. Manajemen Personalia. Jilid 2. Edisi ke-6. Terjemahan. Jakarta: Erlangga

Ghozali, Imam. 2005. Aplikasi Analisis Multivariate dengan SPSS. Semarang: Badan Penerbit UNDIP.

Hamzah B. Uno. 2013. Teori Motivasi dan Pengukurannya: Analisis di Bidang Pendidikan. Jakarta: PT Bumi Aksara.

Handoko, T, Hani. 2008. Manajemen Personalia Sumber Daya Manusia. Edisi Kedua. Yogyakarta: BPFE

Hasibuan, M. 2003. Organisasi dan Motivasi. Dasar Peningkatan Produktivitas. Jakarta: Bumi Aksara.

Kadarisman, M. 2012. Manajemen Pengembangan Sumber Daya Manusia. Jakarta: Rajawali Pers.
Nawawi, Hadari. 2008. Manajemen Sumber Daya Manusia Untuk Bisnis yang Kompetitif. Cetakaan Keempat. Yogyakarta: Gadjah Mada University Press.

Rivai, Veithzal. 2005. Manajemen Sumber Daya Manusia Untuk Perusahaan Dari Teori ke Praktik. Edisi 1. Jakarta: PT Raja Grafindo Persada.

Rivai, Veithzal. 2011. Manajemen Sumber Daya Manusia untuk Perusahaan: dari Teori ke Praktik. Jakarta : RajaGrafindo Persada

Rivai, Veithzal. 2013. Manajemen Sumber Daya Manusia Untuk Perusahaan Dari Teori Ke Praktik. Bandung: Rajagrafindo persada

Sharief, R. Moch Adhitya Azhar. 2016. Pengaruh Motivasi Kerja Terhadap Disiplin Kerja Karyawan Bank Madiwi Cabang Ujungberung Bandung. Skripsi Sarjana (Dipublikasikan). Bandung : Fakultas Ekonomi Universitas Widyatama

Simamora, Henry. 2006. Manajemen Sumber Daya Manusia. Yogyakarta: STIE YKPN

Sugiyono. 2008. Metode Penelitian Kuantitatif, Kualitatif, dan $R \& D$. Bandung: Alfabeta.

Sulistyani, Ambar Teguh dan Rosidah. 2009. Manajemen Sumber daya Manusia. Yogyakarta: Graha Ilmu

Sumarsono, S. 2004. Metode Riset Sumber Daya Manusia. Yogyakarta: Graha Ilmu. 
Sutrisno. 2013. Manajemen Sumber Daya Manusia. Edisi Pertama. Jakarta: Kencana

Undang-Undang Nomor 14 Tahun 2005. Tentang Guru dan Dosen. 2005. Jakarta, Depdiknas A.M, Sardiman. 2007. Interaksi dan Motivasi Belajar. Jakarta: Rineka Cipta.

Allen and Meyer. 2013. The Measurement and Antecedents of Affective, Contintinuance and Normative Commitment to Organitazion. PT Elex Media Komputindo, Jakarta.

Arikunto, S.2013. Prosedur Penelitian: Suatu Pendekatan Praktik. Jakarta: Rineka Cipta.

Bangun, Wilson. 2012. Manajemen Sumber Daya Manusia. Jakarta: Erlangga.

Edy Sutrisno. 2010. Manajemen Sumber Daya Manusia. Edisi Pertama. Cetakan Pertama. Jakarta: Penerbit Kencana

-----------. 2011. Manajemen Sumber Daya Manusia. Jakarta: Penerbit Kencana.

Dessler, Gary. 2016. Manajemen Sumber Daya Manusia, Jilid 1 Edisi 10, Alih Bahasa Jakarta: Paramita Rahaya Indeks.

Ghozali, Imam. 2013. Aplikasi Analisis Multivariate dengan Program IBM SPSS 21. Semarang: Badan Penerbit Universitas Diponegoro.

------. 2016. Aplikasi Analisis Multivariete Dengan Program IBM SPSS 23 (Edisi 8). Cetakan ke VIII. Semarang: Badan Penerbit Universitas Diponegoro.
2017. Model Persamaan Struktual Konsep dan Aplikasi Dengan Program AMOS 24. Semarang: Badan Penerbit Universitas Diponegoro.

----------. 2018. Aplikasi Analisis Multivariate dengan Program IBM SPSS 25. Semarang: Badan Penerbit Universitas Diponegoro.

Hadi, Sutrisno. 2011. Metodologi Research Jilid III. Yogyakarta: Andi Offset.

Handoko, T.Hani. 2003. Manajemen Personalia dan Sumber Daya Manusia. Yogyakarta, BPFE-Yogyakarta.

Handoko, T.Hani. 2011. Manajemen Personalia dan Sumber Daya Manusia. Yogyakarta: Penerbit BPFE.

Hasibuan, S. P. Melayu. 2012. Manajemen Sumber Daya Manusia. Edisi Revisi. Cetakan Ke Tigabelas. Jakarta : Bumi Aksara.

---------. 2016. Manajemen Sumber Daya Manusia. Edisi Revisi. Jakarta: Penerbit PT Bumi Aksara

Hersey. 2004. Kunci Sukses Pemimpin Situasional. Jakarta: Delaprasata.

Husein Umar. 2011. Metode Penelitian untuk Skripsi dan Tesis Bisnis. Jakarta: Rajawali Pers.

Kasmir. 2016. Manajemen Sumber Daya Manusia (Teori dan Praktik). Jakarta: PT Raja Grafindo Persada.

Komalasari, Kokom. 2015. Pembelajaran Kontektual: Konsep dan Aplikasi.Bandung: PT Refika Adiatama. 
Kuncoro, Mudrajad. 2009. Metode Riset Untuk Bisnis \& Ekonomi. Jakarta: Penerbit Erlangga.

Luthans, Fred. 2014. Perilaku Organisasi, (Alih Bahasa V.A Yuwono, dkk), Edisi Bahasa Indonesia, Yogyakarta.

Mangkunegara, Anwar Prabu. 2009. Evaluasi Kinerja Sumber Daya Manusia. Bandung: Penerbit Refika Aditama. 2011. Manajemen Sumber Daya Perusahaan. Bandung: PT . RemajaRosdakarya.

Daya Manusia Perusahaan. Bandung: PT. Remaja Rosdakarya.

Moeheriono. 2010. Pengukuran Kinerja Berbasis Kompetensi. Surabaya: Ghalia Indonesia.

2012. Pengukuran Kinerja

Berbasis Kompetensi. Jakarta: Raja Grafindo Persada.

Mondy, R. Wayne, and Robert M. Noe. 2005. Human Resource Management. Ninth Edition. USA: Prentice Hall.

Rivai, Veithzal. 2011. Manajemen Sumber Daya Manusia untuk Perusahaan: dari Teori ke Praktik, Jakarta: RajaGrafindo Persada.

2013. Kepemimpinan dan Perilaku Organisasi. Jakarta: PT. Raja GrafindoPersada.

Robbins, Stephen P dan Judge. 2007. Perilaku Organisasi. Jakarta: Salemba Empat.
2008. Organizational Behaviour, Tenth Edition (Perilaku Organisasi Edisi ke Sepuluh), Alih Bahasa Drs. Benyamin Molan. Jakarta: Salemba Empat.

2008. Perilaku Organisasi, Jilid

I dan II, alih Bahasa : Hadyana Pujaatmaja. Jakarta: Prenhallindo.

----------. 2011. Perilaku Organisasi.

Edisi 12. Salemba Empat.

Robbins, Stephen P dan Judge. 2015. Perilaku Organisasi. Jakarta: Salemba Empat.

Roziqin, M. Z. 2010. Kepuasan Kerja. Malang: Averroes Press.

Siagian, Sondang P. 2003. Sistem Informasi untuk Pengambilan Keputusan. Jakarta: Gunung Agung.

Sudarmanto. 2009. Kinerja dan Pengembangan Kompetensi SDM. Yogyakarta: Pustaka Pelajar.

Sugiyono. 2010. Metode Penelitian Kuantitatif Kualitatif dan R\&D. Bandung: Penerbit CV Alfabeta.

2012. Metode Penelitian Kuantitatif Kualitatif dan R\&D. Bandung: Penerbit CV Alfabeta.

Suliyanto. 2011. Ekonometrika Terapan: Teori dan Aplikasi Dengan SPSS.Edisi 1. Yogyakarta: ANDI Yogyakarta.

Steers, Richard M. \& Porter, Lyman W. (1991). Motivation and Work Behavior.New York: Mc Graw-Hill.

Wibowo. 2010. Manajemen Kinerja. Jakarta: Rajawali Press. 
Yusuf, Burhanuddin. 2015. Manajemen sumber daya manusia di lembaga keuangan syariah. Jakarta : PT Raja Grafindo Persada. 